\title{
Stimulation of biodiesel production from two algae: Chlorella vulgarisBerjerinckandNitzschiapalea (Kütz.) Smith,and study their some growth parameters under different light intensity.
}

\author{
Fikrat M Hassan ${ }^{1}$ Ibtsam F. Aljbory ${ }^{2}$ Essam F. Al- Jumaily ${ }^{3}$ \\ ${ }^{I}$ College of Science for Women, University of Baghdad, Baghdad-Iraq. \\ ${ }^{2}$ Market Research and Consumer Protection Center, University of Baghdad, Baghdad-Iraq. \\ ${ }^{3}$ Genetic Engineering and Biotechnology Institute-University of Baghdad, Baghdad-Iraq
}

\begin{abstract}
Four different intensities treatments were used to stimulate the biodiesel production from two local isolated algae: Chlorella vulgarisBerjerinck and Nitzschiapalea (Kütz.) Smith. Also the study included the effect of light intensity on growth rates and primary product (carbohydrate and protein). The treatment $300 \mu \mathrm{E} \mid \mathrm{m}^{2}$ Isec was recorded the highest lipid content $10 \%$ of dry weight $(\mathrm{DW})$, highest carbohydrate content (18\% of DW) and highest protein content (58\% of DW) for C.vulgaris. While the alga N. paleathe highest values were recorded for lipid content $(48 \%$ of $\mathrm{DW})$, carbohydrate contents $(22 \%$ of $\mathrm{DW}$ ) and $15 \%$ of $\mathrm{DW}$ for protein content at treatments 300,125 and $268 \mu \mathrm{E} \mathrm{m}^{2} \mathrm{isec}$ respectively. The results revealed that Stearic acid content was increased significantly at the treatments $300 \mu \mathrm{E} \mathrm{m}^{2}{ }^{2} \mathrm{sec}$ for $\mathrm{N}$. palea while the Oleic acid content increased significantly at $300 \mu \mathrm{E} \mid \mathrm{m}^{2} \mathrm{lsec}$ for C.vulgaris. The present study recorded Chrysocapsaplanctonica (West\&West) Plscher as new recorded to Iraq algae flora.

Key words: light intensity, fatty acid, microalgae, Biodiesel, primary product
\end{abstract}

\section{Introduction}

The major disadvantage of using petroleum based fuel is atmospheric pollution. Which are affecting the environment and causing many changes (Klass, 1998).Biodiesel from algae attracted widespread attention in recent years to overcome the expected shortage in a future(Rodolfiet al., 2009).

Algae have ability to fixation $\mathrm{CO}_{2}$ with high efficiency of 10-15 times greater than other higher plants via photosynthesis process and produced biomass for Biofuels production (Khan et al., 2009).Microalgae have been suggested as very good candidates for fuel production because of their advantages of higher photosynthetic efficiency, higher biomass production and faster growth compared to other energy crops and they can grow partially anywhere also use far less water than traditional oilseed crops so there will be no competition with food crops also they are the only feedstock that have the potential to replace transportation fuels (Miao and $\mathrm{Wu}$, 2006).

Biofuel production has focused on terrestrial plants and ethanolproduction from starches. Terrestrial plants have been popular for biofuel production because of the low price for cultivation and production (Huntley and Redalje, 2007).

Terrestrial plants are almost limited by land availability which led to limiting the fuel which can be produced and used by humans, at this time $30-40 \%$ of worldwide primary terrestrial productivity areappropriate for food, fiber, and energy (Huesemann, 2006).

Biofuels are fuels that are derived from organic biomass, rather than minerals, it can be classified into first, second, and third generation biofuels (Koh and Ghazoul, 2008). Austria worked since 1973 after the energy crisis seriously to use biofuel for farm tractors (Pahl, 2008). Laboratory experiments using rapeseed oil for biodiesel production had been a technical success. However, this oil crop was too expensive to be used for biodiesel, since petro-diesel prices were much lower. Therefore, scientists began to look for less expensive feedstock, and they soon discovered that there was a large supply of used cooking oil available (Kulkarni and Dalai, 2006).

Light is available in different quantities and different locations. Only a part (about 45 percent) of the total light spectrum is photo synthetically active radiation thus can be used by algae to capture $\mathrm{CO}_{2}$, during photosynthesis (Gaoet al., 2007). The algae uses light for photosynthesis and growth, therefore, all alga culture systems are shallow and optimized to catch more light. At night (or other dark conditions) photosynthesis cannot occur, so algae consumes stored energy for respiration depending on the temperature and other conditions (Chisti, 2007).Biodiesel can be made from any oil or lipid source such as vegetable oils and animal fats (Felizardoet al., 2006). The oilcontains a glycerol molecule bonded to three fatty acid chains, this structure is called a triglyceride, and it is the major component of the oil (Riekhofet al., 2005). Hassan et al. (2013) was 
studied the effect of different concentrations of nitrogen on lipids production from two microalgae, the study was revealed that nitrogen treatments affected on lipid production of the studied microalgae and produced very high values of Stearic acid and Oleic acid.

The present study aimed to examine the ability of some isolated local algae to produce lipids in different light intensities, also to determine the lipids quality that uses in biodiesel.

\section{Materials and methods}

Fresh water samples of algae were collected by a phytoplankton net (mesh pore $0.2 \mu$ ), from the ponds and artificial canal around University of Baghdad campus in Al-Jadriah in addition to the Tigris river at AlRasheed area. Samples were incubated under suitable and controlled conditions for algal growth $268 \mu \mathrm{E} / \mathrm{m}^{2} / \mathrm{s}$, 16:8 light: dark and $25 \pm 2 \mathrm{C}^{\circ}$.

\section{Algae Isolation and Purification:}

Two methods were used for isolation and purification: The serial dilution method by using ten test tubes, each one contains $9 \mathrm{ml} \mathrm{Chu-10} \mathrm{nutrient} \mathrm{solution,} 1 \mathrm{ml}$ of algal culture was added to the first tube andshake carefully then $1 \mathrm{ml}$ from the first tube transported to the second tube and so on then incubated for two weeks (Prescott, 1982; Hustudtt, 1930). The second method is streaking on plate agar; Chu-10 media solution solidified by $1.5 \%$ agar-agar and sterilized by autoclave, after sterilization Chu-10 with $45-50 \mathrm{C}^{\circ}$ was poured into petri-dishes which left to solidify, sterile loop was used for streaking straight line. Then the plates were kept in a cooled illuminated incubator with light intensity about $268 \mu \mathrm{E} / \mathrm{m}^{2} / \mathrm{s}, 25 \pm 2 \mathrm{C}^{\circ}$ and 16:8 light: a dark periodof 10 -14 days (Sinigallianoet al., 2009).

\section{Preparation and Sterilization of Media:}

Modified Chu-10 was used for the algal growth(Kassimet al., 1999). A stock solution of each salt was prepared by dissolving weight of the salt as it clearly demonstrated in Table (1), $\mathrm{pH}$ was set on 6.4 using $(0.01 \mathrm{~N})$ of sodium hydroxide or hydrochloric acid.

\section{Algae Cultivation for Biomass:}

A $100 \mathrm{ml}$ of isolated alga culture was prepared then transported to $1000 \mathrm{ml}$ ofChu- 10 media and incubated for 14 days. Finally the growth transported to glass pools 5L for mass culture (Kawaguchi, 1980)

\section{Determination of Growth Curve:}

The growth curve was determined for two algaChlorella vulgaris and NitizschiaPalau. Microalgae concentration was determined daily by optical density (OD) measurements at $540 \mathrm{~nm}$ by a UV-Vis spectrophotometer all measurements of the study were triplicates.

The growth rate $(\mathrm{K})$ and doubling time $(\mathrm{G})$ were calculated according to the following equation:

$\left(\log \mathrm{OD}_{\mathrm{t}^{-}} \log \mathrm{OD}_{0}\right.$

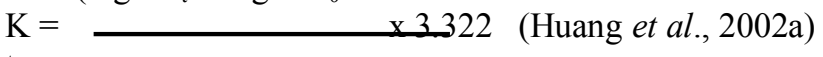

$\mathrm{t}$

0.301

$\mathrm{G}=\frac{}{\mathrm{K}}$ (Huang et al., 2002b)

$\mathrm{t}:$ time (day)

$\mathrm{OD}_{\mathrm{t}}$ : product after $(\mathrm{t})$ day

$\mathrm{OD}_{0}$ : algae at beginning of the experiment zero time

Experimental Design

The light intensity $268 \mu \mathrm{E} \backslash \mathrm{m}^{2} \backslash \mathrm{sec}$ was used for cultivation of studied isolated algae. This intensity was treated as a control in the study experiments; light intensity was measured by a light meter.Three levels of light were used 125,300 and $400 \mu \mathrm{E} \backslash \mathrm{m}^{2} \backslash \mathrm{sec}$ as treatments (Jiminezet al., 2003).

The growth curve was determined for the two studied isolated microalgae, in addition to the growth rate $(\mathrm{K})$ and the doubling time $(\mathrm{G})$ were calculated for each treatment of the study experiments (Li et al., 2008).

\section{Harvesting of Algae:}

Microalgae had been harvested at the beginning of the stationary phase for C. vulgaris harvested on the tenth day but $N$. palea in the twelfth day. 
Each culture of studied algae wascentrifuged in the cooled centrifuge at the laboratories of Center of Market Researches and Consumer Protection, for $3000 \mathrm{r} / \mathrm{min}$ for $15 \mathrm{~min}$, the supernatant removed but organic precipitate had been washed with dilute water. After that it had been dried at $45 \mathrm{C}^{\circ}$ for two days then the dry weight collected to be extracted (Jawad, 1982)

\section{Lipid Extraction:}

One gram of dry weight was put in thimble that was carried to specific cylinders in the soxhlet then $200 \mathrm{ml}$ of solvent (mixture of methanol and hexane 1:1) had been put in the flask after the processtaken threefour hours ( AOAC, 1995).

\section{Lipid analysis:}

Samples were analyzed by High Performance Liquid Chromatography (HPLC) system, model SUPELCO. HPLC consists from a mobile phase which is polar and consists of a mixture of solvents such as water: methane (60:40), while the stationary phase comprises of a column which is usually stainless steel and packed with silica particles, the column is discovery HS C: 18 , dimension $(25 \mathrm{~cm} \times 4.6 \mathrm{~mm} \times 5 \mu \mathrm{m})$, injection flow is $1 \mathrm{ml} / \mathrm{min}$, the absorption at UV $210 \mathrm{~nm}$, and $30^{\circ} \mathrm{C}$ temperature.

\section{Determination of Protein and Carbohydrate:}

Algae samples were centrifuged by cooling centrifuge model Rotina $380 \mathrm{R}$. for $5000 \mathrm{r} / \mathrm{min}$ for $30 \mathrm{~min}$, $4 \mathrm{C}^{\circ}$. The supernatant was collected and the protein determined according to Bradford (1976) and the carbohydrate according to Dubois et al., (1956).

\section{Statistical Analyses}

Complete Randomized Design (C.R.D.) was used as an experimental design. Data were analyzed by using a statistical analysis system- SAS (2001) to study the effect of different concentration factors on the production of lipid. Least significant difference (LSD) was used to compare the significant difference between means at $\mathrm{P} \leq 0.05$.

\section{Isolated Algae}

\section{Results}

Modified Chu-10 was used to cultivate isolated algae specially diatoms and green algae. Six species of microalgae were isolated from artificial waterway in University of Baghdad campus in Al-Jadriah, in addition to the Tigris River at Al-Rasheed area.

These isolated algae were identified according to references (Prescott, 1982;Hustedt, 1930 and Hassan et al. 2012) and to confirm samples they have been sent to the Kuwait Marine Center.The present study recorded Chrysocapsaplanctonica (West\&West) Plscheras new record of algae flora of Iraq. Only two isolated microalgae that were cultivated for this study, they are Chlorellavulgaris and Nitzschiapalea. The isolated algae of the present study are the following:

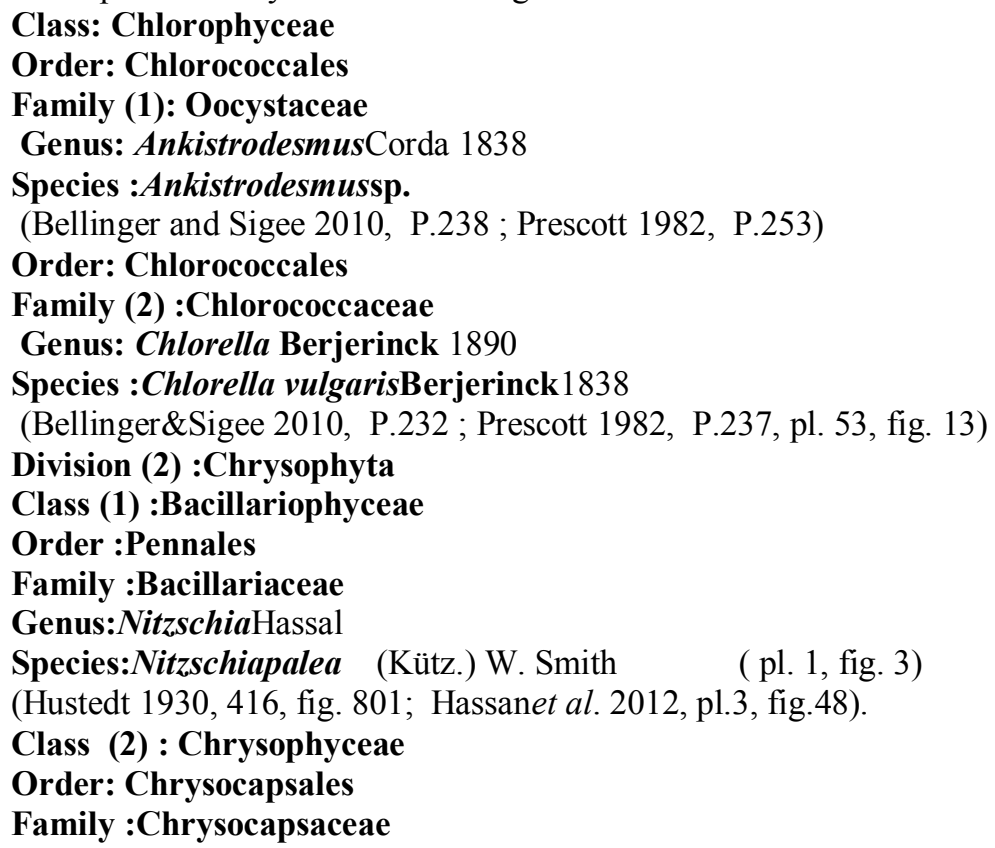


Genus: ChrysocapsaPlscher 1913

Species:Chrysocapsaplanctonica (West\&West) Plscher 1913 (pl. 1, fig. 4), New Record ( acoording to Maulood and Toma 2004)

(Prescott 1982, P. 385, pl. 99, fig. 8).

Division (3): Cyanophyta

Class: Cyanophyceae

Order (1): Nostocales

Family :Nostocaceae

Genus: Anabaena Bory 1822

Species : Anabaena sp.

(pl. 1, fig. 5)

(Bellinger and Sigee 2010, P.164 ; Prescott 1982, P. 510).

Order (2): Oscillatoriales

Family :Oscillatoriaceae

Genus: OscillatoriaVoucher 1803

Species :OscillatorialimneticaLemmermann $1900 \quad$ ( pl. 1, fig. 6)

(Desikachary 1959, P. 226, pl. 37, fig.3 ; Prescott 1982, P.488, pl. 109, fig. 16)

Different growth curve and growth rate $(\mathrm{K})$ were observed for both isolated algae in the treatments, and the harvesting time was also different among the treatments.

Figure (1)illustrates the effect of different levels of light intensity onC. vulgarisbiomass growth. The lag phase of biomass growth took from the day zero to the days 5, 4, 3 and 3 at treatments 125, 268 (control), 300 and 400 $\left(\mu \mathrm{E} \backslash \mathrm{m}^{2} \backslash \mathrm{sec}\right)$, while the log phase took $8,8,6$ and 5 days at treatments $\left(25,268,300\right.$ and $400\left(\mu \mathrm{E} \backslash \mathrm{m}^{2} \backslash \mathrm{sec}\right)$.

The stationary phase began in the days $13,12,9$ and 8 for treatments $125,268,300$ and $400\left(\mu \mathrm{Elm}{ }^{2} \backslash \mathrm{sec}\right)$ light intensity respectively. The highest $\mathrm{K}$ value was 0.1 in the control treatment $\left(268 \mu \mathrm{Elm}^{2} \backslash \mathrm{sec}\right)$, while the lowest $\mathrm{K}$ value was 0.06 at $\left(400 \mu \mathrm{E} \backslash \mathrm{m}^{2} \backslash \mathrm{sec}\right)$ but at $\left(300 \mu \mathrm{E} \backslash \mathrm{m}^{2} \backslash \mathrm{sec}\right)$ the $\mathrm{K}$ value was 0.098 as it shown in (Table2 and figure 3 )

The shortest doubling time (G)was 2.7 days at a control treatment while the longest was 5 days at $(400 \mu \mathrm{E} \backslash \mathrm{m}$

${ }^{2} \backslash \mathrm{sec}$ ) and at 125 and $\left(300 \mu \mathrm{E} \backslash \mathrm{m}^{2} \backslash \mathrm{sec}\right),(\mathrm{G})$ was 3.3 and 3 days respectively (Table3 and figure 4).

The alga N.palea entered astationary phase in different days among treatments, the lag phase began from the day zero to the days $5,4,3$ and 3 then the alga entered to $\log$ phase which was continued till the stationary phase began. The stationary phase was begun in $12,11,10$ and 8 in treatments $125,268,300$ and $400 \mu \mathrm{E} \mathrm{Em}^{2}$ ।sec respectively (figure 2). The highest $\mathrm{K}$ value was 0.13 at the treatment $125 \mu \mathrm{E} / \mathrm{m}^{2}$ ।sec, while the lowest value was 0.03 at $400 \mu \mathrm{E} \backslash \mathrm{m}^{2}$ isec (Table 2 and figure2). The shortest doubling time (G) was 2.3 days at treatment $125 \mu \mathrm{E} \backslash \mathrm{m}^{2} \backslash \mathrm{sec}$, while the longest was 10 days at $400 \mu \mathrm{E} \backslash \mathrm{m}^{2} \backslash \mathrm{sec}$ (Table 3 and figure 6)

The lipid yield (\%) for C. vulgaris was increased from $6 \%$ in the treatment of $125 \mu \mathrm{E} \backslash \mathrm{m}^{2} \backslash \mathrm{sec}$ to $10 \%$ inthe treatment of $300 \mu \mathrm{Elm}{ }^{2}$ isecsignificantly, while other treatments were increased comparison with control treatment but not significantly(Table4, figure 12). The lipidyield (\%)forN.paleawasincreased from $38 \%$ in 125 ( $\left.\mu \mathrm{E} \backslash \mathrm{m}^{2} \backslash \mathrm{sec}\right)$ to $48 \%$ in $300\left(\mu \mathrm{E} \backslash \mathrm{m}^{2} \backslash \mathrm{sec}\right)$ significantly, also some increasing in lipid yield was noticed but not significant in comparison with control treatment expect of treatment $300 \mu \mathrm{E} \backslash \mathrm{m}^{2} \backslash \sec ($ Table4 and 13).

Light alsoaffected the two studied fatty acids that were analyzed by HPLC, Stearic acid (18:0) and Oleic acid (18:1). In Chlorella vulgaristheStearic acid was recorded decreased content in all studied treatments comparison with control, while the treatment $300 \mu \mathrm{E} / \mathrm{m}^{2}$ ।sec has significantly higher content from other treatment expect with control treatment and the lowest value was recorded at the treatment $125 \mu \mathrm{E} / \mathrm{m}^{2} \mathrm{isec}$ ( Table 5, figures 6 and 10 ). Oleic acid value was increased at $300 \mu \mathrm{E} \backslash \mathrm{m}^{2}$ \secsignificantly. The lowest value was recorded at $125 \mu \mathrm{E} \backslash \mathrm{m}^{2} \backslash \mathrm{sec}$ (Table 6and figures7 and 10).

In Nitzschiapalea Stearic acid increased from $0.8 \%$ at $125\left(M E \backslash m^{2} \backslash s e\right)$ to $4.5 \%$ at $300\left(\mu \mathrm{E} \mathrm{m}^{2}\right.$ (sec) , then it decreased to $2 \%$ at treatment $400 \mu \mathrm{E} \backslash \mathrm{m}^{2}{ }^{2} \mathrm{sec}$, only the increased values of the treatment 300 $\mu \mathrm{E} \backslash \mathrm{m}^{2} \backslash$ sec was significant comparison with control (Table 5). The Oleic acid values in all treatment was less than control treatment, the lowest value was $0.06 \%$ at $125 \mu \mathrm{E} \backslash \mathrm{m}^{2} \backslash \mathrm{sec}$ (figures8, 11).

Carbohydrate of $C$. vulgaris was increased from $15 \%$ to $18 \%$ when light increased from $125 \mu \mathrm{E} \backslash \mathrm{m}^{2}$ Isec to $300 \mu \mathrm{E} \backslash \mathrm{m}^{2} \backslash \mathrm{sec}$, and it was $14.5 \%$ at $400\left(\mu \mathrm{E} \backslash \mathrm{m}^{2} \backslash \mathrm{sec}\right)$, only the treatment $300 \mu \mathrm{E} \backslash \mathrm{m}^{2} \backslash \mathrm{sec}$ was increase value from control significantly (Table 7, figure 12) . Carbohydrate content of N. palea was decreased 
from $22 \%$ to $15 \%$ at treatments 125 and $400 \mu \mathrm{E} \backslash \mathrm{m}^{2} \backslash \mathrm{sec}$ respectively, and it was $18 \%$ at $300 \mu \mathrm{E} \backslash \mathrm{m}^{2} \backslash \mathrm{sec}(\mathrm{Table} 7$ and figure 13).

Protein content of $C$. vulgaris increased significantly at treatment ( 58\%) at $300 \mu \mathrm{E} \backslash \mathrm{m}^{2} \backslash$ sec.the lowest value was $38 \%$ at $400 \mu \mathrm{E} \backslash \mathrm{m}^{2} \backslash \mathrm{sec}$ (Table 8 and figure 12). In N. palea Protein content decreased from $13 \%$ to $8.5 \%$ when light increased from 125 to $400\left(\mu \mathrm{E} \backslash \mathrm{m}^{2} \backslash \mathrm{sec}\right)$, and it was $12.6 \%$ at $300 \mu \mathrm{E} \backslash \mathrm{m}^{2} \backslash \mathrm{sec}$ ( Table 9 and figure 13).

\section{Discussion}

The present study results revealed that the effect of different levels of light intensities on biomass growth for both isolated algae $(C$. vulgaris and $N$. palea) showed no significant differences among treatments and control, whichmaydue to capability of photo acclimation (Chisti, 2007).

The $\mathrm{K}$ value for both isolated algae was increased in low light intensity then it decreased when increased light intensity, but no significant differencesbetween treatments and control was recorded in the present study.Light abundance in low intensity will encourage photosynthesis rate which is more than photorespiration rate so the culture biomass will increase, but when the alga is exposed to high light intensity a photo-oxidative has occurredwhich leads to pigment damages (Litchman, 2000).

The doubling time was increased at high light intensity and a significant difference was recorded between zero treatment and control while there are no significant differences among other treatments comparison with control, but in $N$. palea showed a significant difference between control and treatments $300,400 \mu \mathrm{E} \backslash \mathrm{m}^{2} \backslash \mathrm{sec}$. . The decreasing of growth rate led to a slowing of cell division so doubling cells took more time (Al-Saadiet al., 1996).

The results of the present study is in agreement with a study by Hassan et al.(2004) which reported that the growth rate of Micocystisaeruginosa was increased from 0.42 at $20 \mu \mathrm{E} \backslash \mathrm{m}^{2} \backslash$ sec to 0.48 at $40 \mu \mathrm{E} \backslash \mathrm{m}^{2}$ lsec. Other studies reported that the best light intensity for the growing of two green algae like Scenedesmusacutus, S. quadriquada is $380 \mu \mathrm{E} \backslash \mathrm{m}^{2} \backslash \sec (\mathrm{Kassim}, 1998)$. Light limitation will increase pigment content of most species. Several studies reported that the light limitation will lead to the increase of algal pigment content and the growth was reduced at both below and above optimum light intensity in several treatments can become stressful and lead to photo inhibition by damaging the chlorophyll pigments and that may hold theculture entering to death phase (Litchman, 2000; Al- Saadi, et al., 1996).

The lipid content of both isolated algae was increased especially at $300 \mu \mathrm{E} \backslash \mathrm{m}^{2} \backslash$ sectreatment, there was a significant difference between this treatment and other treatments, lipids show highest and fastest response to the light intensity changes than of carbohydrate and proteins (Solovchenkoet al., 2008).

Total lipid content increased according to growth phases, some studies reported that total fatty acids of green algae Parietochlorisinciseincreased from $43 \%$ at $\log$ phase to $77 \%$ at stationary phase, and also as in Gymnodiniumsp total fatty acids increased from $8 \%$ at log phase two $30 \%$ at stationary phase (Mansouret al., 2003).

A study on Spirulinasp found that low light intensity $\left(35 \mu \mathrm{E} \backslash \mathrm{m}^{2} \backslash \mathrm{sec}\right)$ induces lipid production and high light intensity $\left(400 \mu \mathrm{E} \mathrm{m}^{2} \backslash \mathrm{sec}\right)$ leads to less lipid content(Solovchenkoet al., 2008). Another study on the green algae Haematococcuspluvialis which was exposed to high light intensity $\left(350 \mu \mathrm{E} \backslash \mathrm{m}^{2} \backslash \mathrm{sec}\right)$ and that stimulated high production of lipid content as an accumulate way to resist this stress, but even with this photoprotection, photoinhibition due to light damage can still occur (Zhekisheva et al., 2002). Similar results were reported in the present study.

Stearic acid content in both studied microalgae recorded highest content at $300 \mu \mathrm{E} \backslash \mathrm{m}^{2} \backslash$ sec treatment, while lower content at $125 \mu \mathrm{E} \backslash \mathrm{m}^{2} \backslash \mathrm{sec}$. There are significant differences between the two isolated algae, and significant differences among treatments. Oleic acid content showed no significant differences between two algae at $125,300 \mu \mathrm{E} \mathrm{mm}^{2} \backslash \mathrm{sec}$ treatments and significant differences among treatments for each alga. This increasing of Stearic and Oleic acids followed the increasing of total lipids, similar results for other algae species were reported by other authors (Solovchenkoet al., 2008).

The present study results of fatty acids are in agreement with those reported byAfifyet al. (2010). The Stearic acid (18:0) is considered as the most common fatty acid in biodiesel that is present in this study that encourage to use the studied algae to produce biodiesel in addition to increasing of Oleic acid (18:1).

The carbohydrate content of both isolated algaewas increased with the increasing of light intensity, but the treatment $400 \mu \mathrm{E} \backslash \mathrm{m}^{2} \backslash \mathrm{sec}$ was decreased. A significant difference was recorded among treatments of both algae. 
The increasing in carbohydrate contents may be as a response to increasing in the photosynthesis process (Clayton and King, 1990).

There are alternative pathways to convert lipids andlor carbohydrate to TAG that has recently been demonstrated in plants, bacteria and yeast, but have not yet been studied in algae, and these pathways are worth investigating for improving lipid production (Arabolazaet al., 2008). The present study results of carbohydrate agreed with another study (Rafiqualet al., 2005) that reported increases in carbohydrate from $0.8 \%$ to $7.1 \%$ of DW when exposed to high light. Highest carbohydrate content was reported $28.8 \%$ forOscillatoriasp when exposed to high intensity of light (Nagle et al., 2010), Another study showed that high intensity of light effect on the second photo system which is responsible for splitting the water molecule (Adriet al., 2003).

The protein content was higher in C. vulgaris than in N. palea (Convertiet al., 2009). Significant differences were recorded among treatments at both studied microalgae. The results of this present study can be explained on the basis of light effect on algal growth which led to increasing the organic compounds including proteins (Dybleet al., 2006), and also effect on the nitrogen which is the most important element that enters to the amino acids synthesis and the activities of enzymes that are responsible for protein syntheses and regulation (Saradaet al., 2002).

\section{Acknowledgments}

The authors' wishes to thanks Prof Dr. Faiza Yamani from Kuwait institute for Scientific Research for their assistance. Also thanks the college of Science for Women for their support this work.

\section{References}

[1] Adri,N., Zer,H., Shochats,S. and Ohadi, I. (2003). Photoinhibition: ahistorical perspective. Photosynth.Res.76:343-370.

[2] Afify, A.M.R., Shalaby, E. A. and Sanaa, M.M.S. (2010). Enhancement of biodiesel production from different species of algae.Grasas Y Aceites, 61(4):416-422.

[3] AL-Saadi, H.A., AL-Lami, A.A. and Kassim, T.I.(1996). Algal ecology and composition in Garmat Ali River. Iraq RegRiv.12(1):27-38.

[4] AOAC (Association of Official Analytical Chemists). (1995). Official Methods of Analysis, 16 ${ }^{\text {th }}$ Edition.AOAC International, Gaithersburg, MD

[5] Arabolaza, A., Rodrigues, E., Altabe, S., Alvarez, H. and Gramajo, H. (2008).Multiple pathways for triacylglycerol biosynthesis in Streptomyces coelicolor.Appl.Enviro.Micro. 74(9):2573-2582.

[6] Bellinger, E.G. and Sigee, D.C. (2010) Freshwater Algae Identification and use as Bioindicators. John Wileg and Sons, Ltd pp.271.

[7] Chisti, Y.(2007).Biodiesel from Microalgae. J. Biotechnology Advances. 25:294-305.Clayton, M.N. and King, R.J. (1990)f. Biology marine plant, Longman Cheshire, Melbourne.

[8] Converti, A., Casazaa, A.A., Ortiz, E.Y., Perego, P. and DelBorghi, M. (2009). Effect of temperature and nitrogen concentration on the growth and lipid content of Nannochloropsisoculata and Chlorella vulgaris for biodiesel production.Chem.Eng. Process. 48:1146-1151.

[9] Dubois, M., Gilles,K.A., Hamiton, J.K., Robers, P.A.and Smith, F.(1956).Colorimetric method for determination of sugars and substances.Anal.Chem.228(3):350-356.

[10] Dybel, J. , Tester, P.A. and Litaker, R.W. (2006). Effects of light intensity on Cylindrospermopsin production in the cyanobacterial HAB species Cylindrospermopsisraciborskii .African J. Mar.Sci. 28(2) : 309-312 .

[11] Felizardo, P., Coo, M.J.N., Raposo, I., Mendes, J.F., Berkemeier, R., Bordado, J.M.(2006). Production of biodiesel from waste frying oil. WasteManag. 26(5):487-494.

[12] Gao, K. S., Wu, Y. P., Li, G., Wu, H. Y., Villafane, V. E. and Helbling, E.W. (2007). "Solar UV radiation drives CO2 fixation in marine phytoplankton: A double edged sword." Plant Physiol. 144(1): 54-59.

[13] Hassan, F.M., Hadi, R.A., Kassim, T.I. and Al-Hassany, J.S. (2012). Systematic study of epiphytic algal after restoration of AlHawizah marshes, southern of Iraq. Int. J. Aqua. Sci. 3(1):37-57.

[14] Hassan, F. M., Yaseen, A. A. and Abed, R. K. (2004). Effect of different temperture and light intensity on growth of algae Microcystisaeruginosa.J.Babylon Univ.,9(3):609-620. (inarbic).

[15] Hassan, F. M. Aljobory, I. F., and Kassim, T. I. (2013). An attempt to Stimulate lipids for Biodiesel Production from locally Isolated Microalgae in Iraq. J. Baghdad for Sci. 10 (1): 97-108.

[16] Huang, X.H.; Li, C.L.; Liu, C.W. and Zeng, D.Q.(2002a). Studies on the Ecological Factors of Oocystisborgei. J. Zhanjiang Ocean University. 22( 3): 8-12.

[17] Huang, X.H., Li, C.L., Liu, C.W., Wang, Z.D. and Chen, J.J. (2002b). Studies on the N and P nutrient demand if Nannochlorisoculata. J. MarineSciences(China). 26(8): 13-17.

[18] Huesemann, M.H.(2006). Can advances in science and technology prevent global warming? A critical review of limitations and challenges.Mitigation and Adaptation Strategies for Global Change. 11: 539-577

[19] Huntley, M. and Redalje, D. (2007). CO2 Mitigation and Renewable Oil from Photosynthetic Microbes: A New Appraisal. J. Mitigation and Adaptation Strategies for Global Climate Change. 12(4): 573-608.

[20] Hustedt, F. (1930). Bacillariophyta (Diatomite). In: Die Süsswasser - Flora Mitteleuropas. Heft. 10, 2.Aufl. (Pascher, A. Eds), pp. 466.

[21] Jawad, A.M. (1982). Interaction between cyanobacteria and other micro-organisms. Ph.D. Thesis. Liverpool University. England.

[22] Jiminez, C., Cossio, B.R. and Niell, F.X.(2003). Relationship Between Physiochemical variables and productivity in open ponds for the production of Spirulina: A predictive model of algal yield'. J. Aquaculture 221(4): 331-345.

[23] Kassim, T.I.(1998).Production of some phyto and Zooplankton and their use as a live food for fish larva. PH.D. Thesis, Univ. of Basrah

[24] Kassim, T.I., Al-Saadi, H. and Salman, N.A.(1999). Production of some phyto-and zooplankton and their use as live food for fish larva. Iraqi J. Agric. Proc. of $2^{\text {nd }}$ Sci.Confer.4(5):188-201.

[25] Kawaguchi, K.(1980). Microalgae production systems in Asia.Algae Biomass. J. Biomedical Press, Amsterdam, pp 25-33. 
[26] Khan, S. A., Rashmi. Mirza.Hussain,S. P. and Banerjee, U. C. (2009). Prospects of biodiesel production from microalgae in India. New Delhi. India. Renewable and Sustainable Energy Reviews.13(9):2361-2372.

[27] Klass, L. D. (1998). Biomass for Renewable Energy, Fuels and Chemicals. Academic Press, New York. pp 1-2.

[28] Koh, L.P. and Ghazoul, J.(2008). Biofuels, biodiversity, and people: understanding the conflicts and finding opportunities. J. Biological Conservation. $141: 2450-2460$.

[29] Kulkarni, M. G. and Dalai, A. K. (2006).Waste cooking oil-an economical source for biodiesel: A review.Ind.Eng.Chem.Res.45:2901-2913.

[30] Li, Y., Horsman, M., Wu, N., Lan, C.Q. and Dubois-Calero, N. (2008). Biofuels from Microalgae.Biotechnol.Prog. 24:815-820.

[31] Litchman, E. (2000). Growth rates of phytoplankton under fluctuating light.Freshwat.Biol.44,223-235.

[32] Mansour, M.P., Volkman, J.K and Blackburn, S.I. (2003). The effect of growth phase on the lipid class, fatty acid and sterol composition in the marine dinoflagellate,Gymnodinium sp.in batch culture.Phytochemistry, 63:145-153.

[33] Miao, X. and Wu, Q. Y. (2006). Biodiesel Production from Heterotrophic MicroalgalOil .Bioresour.Technol. 97: 841 -846.

[34] Nagle, V.L., Mhalsekar, N.M. and Jagtap, T.G. (2010). Isolation, optimization and characterization of selected cyanophyceanmembers.IndianJ.Mar.Sci.39(2):312-318.

[35] Pahl, G. (2008). Biodiesel: growing a new energy economy. 2nd Edition.Foreward by Bill McKibben. United States.

[36] Prescott, G.W. (1982).Algae of the Western Great Lakes Areas. Willam, C.; Brown, C.O .Pub. Dubuque. I. Lowa,16 ${ }^{\text {th }}$ printing.

[37] Rafiqul, I.M., Jalal, K.C.A. and Alam, M.Z. (2005). Environmental factors for Optimization of Spirulina biomass in lablatory culture. Bio. Tech. 4(1):19-22.

[38] Riekhof, W.R., Srars, B.B. and Benning, C.(2005).Annotation of genes involved in glycerolipid biosynthesis in Chlamydomonasreinhardtii :Discovery of the betaine lipid synthase BTA 1Cr. Eukaryotic Cell. 4(2):242-252.

[39] Rodolfi, L., Zittelli, G.C., Bassi, N., Padovani, G., Biondi, N., Bonini, G. and Tredici, M. R. (2009). Microalgae for oil: strain selection, induction of lipid synthesis and outdoor mass cultivation in a low-cost photo bioreactor. Biotechnol.Bioeng. 102(1): $100-112$.

[40] Sarada, R. , Bhattacharya, S. and Ravishankar, G.A. (2002). Optimization of culture conditions for growth of the green alga Haematococcuspluvialis. World J. Microbiol. Biotechnol.18 : 517-521.

[41] SAS (Statistical Analysis System).(2004). User's Guide.Statistical.Version $7^{\text {th }}$ ed. SAS.Inst.Inc. Cary.N.C. USA.

[42] Sinigalliano, C.D.; Winshell, J.; Guerrero, M.A.; Scorzetti, G.; Fell, J.W.; Eaton, R.W.; Brand, L. and Rein, K.S.(2009). Viable cell sorting of dinoflagellates by multiparametric flow cytometry. Phycologia 48:249-257.

[43] Sukenik, A., Carmeli, Y. and Berner, T.(1989). Regulation of fatty acid composition by irradiance level in the eustigametophyteNanochoropsissp.J.Phycol.25:686-92.

[44] Solovchenko, A.E., Khozin-Goldberg.I., Dioli-Cohen,S., Cohen,Z.andMerzlyak,M.N.(2008).Effect of light intensity and nitrogen starvation on growth, total fatty acids and arachidonic acid in the green Microalgae Parietochloris incisq.J.AppI.Phycol.20:245-251.

Table (1) Thecomponent concentration of modified Chu-10 medium and the concentration of each component

\begin{tabular}{|c|c|c|}
\hline $\begin{array}{lll}\begin{array}{l}\text { Number } \\
\text { solution }\end{array} & \text { of stock } \\
\end{array}$ & Chemical formula of each salt & $\begin{array}{c}\text { Concentration } \\
\mathrm{g} / \mathrm{l} \\
\end{array}$ \\
\hline 1 & $\mathrm{MgSo}_{4} \cdot 7 \mathrm{H}_{2} \mathrm{O}$ & 10 \\
\hline 2 & $\mathrm{~K}_{2} \mathrm{HPO}_{4}$ & 4 \\
\hline 3 & $\begin{array}{l}\mathrm{NaNO}_{3} \\
\mathrm{CaCl}_{2}\end{array}$ & $\begin{array}{c}8 \\
16\end{array}$ \\
\hline 4 & $\mathrm{FeCl}_{3}$ & 0.32 \\
\hline 5 & EDTA-Na2 & 4 \\
\hline 6 & $\mathrm{NaCl}$ & 30 \\
\hline 7 & $\mathrm{Na}_{2} \mathrm{CO}_{3}$ & 8 \\
\hline 8 & $\begin{array}{c}\mathrm{MnCl}_{2} \cdot 4 \mathrm{H}_{2} \mathrm{O} \\
(\mathrm{NH} 4) 6 \mathrm{Mo}_{7} \mathrm{O}_{24} \cdot 4 \mathrm{H}_{2} \mathrm{O} \\
\mathrm{ZnSO}_{4} \cdot 7 \mathrm{H}_{2} \mathrm{O} \\
\mathrm{CuSO}_{4} \cdot 5 \mathrm{H}_{2} \mathrm{O} \\
\mathrm{COCl}_{2} \cdot 6 \mathrm{H}_{2} \mathrm{O} \\
\mathrm{H}_{3} \mathrm{BO}_{3} \\
\end{array}$ & $\begin{array}{c}0.02 \\
0.028 \\
0.224 \\
0.08 \\
0.004 \\
0.288 \\
\end{array}$ \\
\hline 9 & $\mathrm{Na}_{2} \mathrm{SiO}_{3}$ & 5.7 \\
\hline
\end{tabular}

Table (2). Effect of different levels of light intensities (mean \pm SE) of cultivated conditions on growth rate (K) of studied microalgae

\begin{tabular}{|c|c|c|c|}
\hline \multirow{2}{*}{$\begin{array}{l}\text { Light intensity } \\
\left(\mu \mathrm{E} \backslash \mathrm{m}^{2} \backslash \mathrm{sec}\right)\end{array}$} & \multicolumn{2}{|c|}{ Microalgae } & \multirow[t]{2}{*}{ LSD value } \\
\hline & C. vulgaris & N.palea & \\
\hline 125 & $0.09 \pm 0.01 \mathrm{~A}$ & $0.13 \pm 0.02 \mathrm{~A}$ & $0.11 \mathrm{NS}$ \\
\hline 268(control) & $0.1 \pm 0.0 \mathrm{~A}$ & $0.06 \pm 0.01 \mathrm{~B}$ & $0.052 \mathrm{NS}$ \\
\hline 300 & $0.098 \pm 0.01 \mathrm{~A}$ & $0.05 \pm 0.01 \mathrm{~B}$ & $0.067 \mathrm{NS}$ \\
\hline 400 & $0.06 \pm 0.01 \mathrm{~A}$ & $0.03 \pm 0.0 \mathrm{~B}$ & $0.045 \mathrm{NS}$ \\
\hline LSD Value & $0.04 \mathrm{NS}$ & $0.041 *$ & $\begin{array}{l}--- \\
\end{array}$ \\
\hline
\end{tabular}

$*(\mathrm{P}<0.05)$. 
NS: non-significant.

Means having different letters at the same column are significantly different.

Table (3) Effect of different levels of light intensities (mean \pm SE)of cultivated conditions on doubling time(G) of studied microalgae

\begin{tabular}{|c|c|c|c|}
\hline \multirow{2}{*}{$\begin{array}{l}\text { Light intensity } \\
\left(\mu \mathrm{E} \backslash \mathrm{m}^{2} \backslash \mathrm{sec}\right)\end{array}$} & \multicolumn{2}{|c|}{ Microalgae } & \multirow{2}{*}{ LSD value } \\
\hline & C. vulgaris & N. palea & \\
\hline 125 & $3.3 \pm 0.02 \mathrm{~B}$ & $2.3 \pm 0.12 \mathrm{~B}$ & 0.784 * \\
\hline 268(control) & $2.7 \pm 0.02 \mathrm{~B}$ & $5 \pm 0.36 \mathrm{~B}$ & $1.03 *$ \\
\hline 300 & $3 \pm 0.05 \mathrm{~B}$ & $6 \pm 0.49 \mathrm{AB}$ & 1.77 * \\
\hline 400 & $5 \pm 0.07 \mathrm{~A}$ & $1010 \pm 0.86 \mathrm{~A}$ & $2.52 *$ \\
\hline LSD Value & $1.045 *$ & $4.021 *$ & ב--- \\
\hline
\end{tabular}

$*(\mathrm{P}<0.05)$.

NS: non-significant.

Means having different letters at the same column are significantly different.

Table (4) Effect of different levels of light intensities (mean \pm SE) of cultivated conditions on Lipid yield(\%)of studied microalgae.

\begin{tabular}{|c|c|c|c|}
\hline \multirow{2}{*}{$\left(\mu \mathrm{E} \backslash \mathrm{m}^{2} \backslash \mathrm{sec}\right)$} & \multicolumn{2}{|c|}{ Microalgae } & \multirow[t]{2}{*}{ LSD value } \\
\hline & C. vulgaris & N. palea & \\
\hline 125 & $6 \pm \mathrm{B} 0.23$ & $38 \pm 1.52 \mathrm{~B}$ & $7.48 *$ \\
\hline 268(control) & $6.5 \pm 0.28 \mathrm{~B}$ & $440 \pm 2.19 \mathrm{~B}$ & $7.81 *$ \\
\hline 300 & $10 \pm 1.02 \mathrm{~A}$ & $48 \pm 2.78 \mathrm{~A}$ & $6.95 *$ \\
\hline 400 & $7.5 \pm$ B 0.57 & $41 \pm 1.77 \mathrm{~B}$ & $8.02 *$ \\
\hline LSD Value & $2.388^{*}$ & $5.39 *$ & $\begin{array}{l}---- \\
\end{array}$ \\
\hline
\end{tabular}

$*(\mathrm{P}<0.05)$.

Means having different letters at the same column are significantly different.

Table (5) Effect of different levels of light intensities (mean \pm SE) of cultivated conditions on Stearic acid (\%) content of studied microalgae

\begin{tabular}{|c|c|c|c|}
\hline \multirow{2}{*}{$\begin{array}{l}\text { Light intensity } \\
\left(\mu \mathrm{E} \backslash \mathrm{m}^{2} \backslash \mathrm{sec}\right)\end{array}$} & \multicolumn{2}{|c|}{ Microalgae } & \multirow[t]{2}{*}{ LSD value } \\
\hline & C. vulgaris & N. palea & \\
\hline 125 & $0.1 \pm \mathrm{B} 0.00$ & $0.8 \pm 0.02 \mathrm{~B}$ & $0.37 *$ \\
\hline 268 (control) & $0.7 \pm 0.04 \mathrm{~A}$ & $21.5 \pm 0.07 \mathrm{~B}$ & $0.59 *$ \\
\hline 300 & $0.6 \pm 0.04 \mathrm{~A}$ & $4.5 \pm 0.14 \mathrm{~A}$ & $1.02 *$ \\
\hline 400 & $0.19 \pm 0.02 \mathrm{~B}$ & $2 \pm 0.05 \mathrm{~B}$ & $0.66 *$ \\
\hline LSD Value & $0.171^{*}$ & $1.55 *$ & ---- \\
\hline
\end{tabular}

* $(\mathrm{P}<0.05)$.

Means having different letters at the same column are significantly different.

Table (6) Effect of different levels of light intensities (mean \pm SE) of cultivated conditions on Oleic acid (\%) content of studied microalgae

\begin{tabular}{|c|c|c|c|}
\hline \multirow{2}{*}{$\begin{array}{l}\text { Light intensity } \\
\left(\mu \mathrm{E} \backslash \mathrm{m}^{2} \backslash \mathrm{sec}\right)\end{array}$} & \multicolumn{2}{|c|}{ Microalgae } & \multirow[t]{2}{*}{ LSD value } \\
\hline & C. vulgaris & N. palea & \\
\hline 125 & $0.03 \pm 0.0 \mathrm{~B}$ & $0.06 \pm 0.01 \mathrm{~B}$ & $0.05 \mathrm{NS}$ \\
\hline 268(control) & $0.05 \pm 0.0 \mathrm{~B}$ & $2 \pm 0.05 \mathrm{~A}$ & $0.16^{*}$ \\
\hline 300 & $0.2 \pm 0.0 \mathrm{~A}$ & $1.6 \pm 0.03 \mathrm{~A}$ & $0.57 \mathrm{NS}$ \\
\hline 400 & $0.04 \pm 0.0 \mathrm{~B}$ & $0.20 \pm 0.0 \mathrm{~A}$ & $0.08 *$ \\
\hline LSD Value & $*_{0.033}$ & $0.081 *$ & $\begin{array}{l}--- \\
\end{array}$ \\
\hline
\end{tabular}

$*(\mathrm{P}<0.05)$.

NS: non-significant.

Means having different letters at the same column are significantly different. 
Table (7)Effect of different levels of light intensities(mean \pm SE)of cultivated conditions on Carbohydrate (\%)content of studied algae.

\begin{tabular}{|c|c|c|c|}
\hline \multirow{2}{*}{$\begin{array}{l}\text { Light intensity } \\
\left(\mu \mathrm{E} \backslash \mathrm{m}^{2} \backslash \mathrm{sec}\right)\end{array}$} & \multicolumn{2}{|c|}{ Microalgae } & \multirow[t]{2}{*}{ LSD value } \\
\hline & C. vulgaris & N. palea & \\
\hline 125 & $15 \pm 1.06 \mathrm{C}$ & $22 \pm 1.47 \mathrm{~A}$ & $3.48 *$ \\
\hline 268 (control) & $16.5 \pm 1.25 \mathrm{~B}$ & $20 \pm 0.79 \mathrm{AB}$ & $2.39 *$ \\
\hline 300 & $18 \pm 1.55 \mathrm{~A}$ & $18 \pm 0.52 \mathrm{BC}$ & $0.00 \mathrm{NS}$ \\
\hline 400 & $14.5 \pm 0.85 \mathrm{D}$ & $15 \pm 0.36 \mathrm{C}$ & $1.233 \mathrm{NS}$ \\
\hline LSD Value & $1.215^{*}$ & $3.91 *$ & ---- \\
\hline
\end{tabular}

$*(\mathrm{P}<0.05)$. NS: non-significant.

Means having different letters at the same column are significantly different.

Table (8) Effect of different levels of light intensities(mean \pm SE) ofcultivated conditions on Protein \% content of studied microalgae.

\begin{tabular}{|c|c|c|c|}
\hline \multirow{2}{*}{$\begin{array}{l}\text { Light intensity } \\
\left(\mu \mathrm{E} \backslash \mathrm{m}^{2} \backslash \mathrm{sec}\right)\end{array}$} & \multicolumn{2}{|c|}{ Microalgae } & \multirow[t]{2}{*}{ LSD value } \\
\hline & C. vulgaris & N. palea & \\
\hline 125 & $40 \pm 2.18 \mathrm{C}$ & $13 \pm 0.46 \mathrm{~A}$ & $7.61 *$ \\
\hline 268(control) & $50 \pm 2.51 \mathrm{~B}$ & $15 \pm 0.02 \mathrm{~A}$ & $11.48 *$ \\
\hline 300 & $58 \pm 2.88 \mathrm{~A}$ & $12.6 \pm 0.44 \mathrm{~A}$ & $13.09 *$ \\
\hline 400 & $38 \pm 1.69 \mathrm{C}$ & $8.5 \pm 0.37 \mathrm{~B}$ & $7.68 *$ \\
\hline LSD Value & $6.48 *$ & $2.79 *$ & ב--- \\
\hline
\end{tabular}

$*(\mathrm{P}<0.05)$.

Means having different letters at the same column are significantly different. 

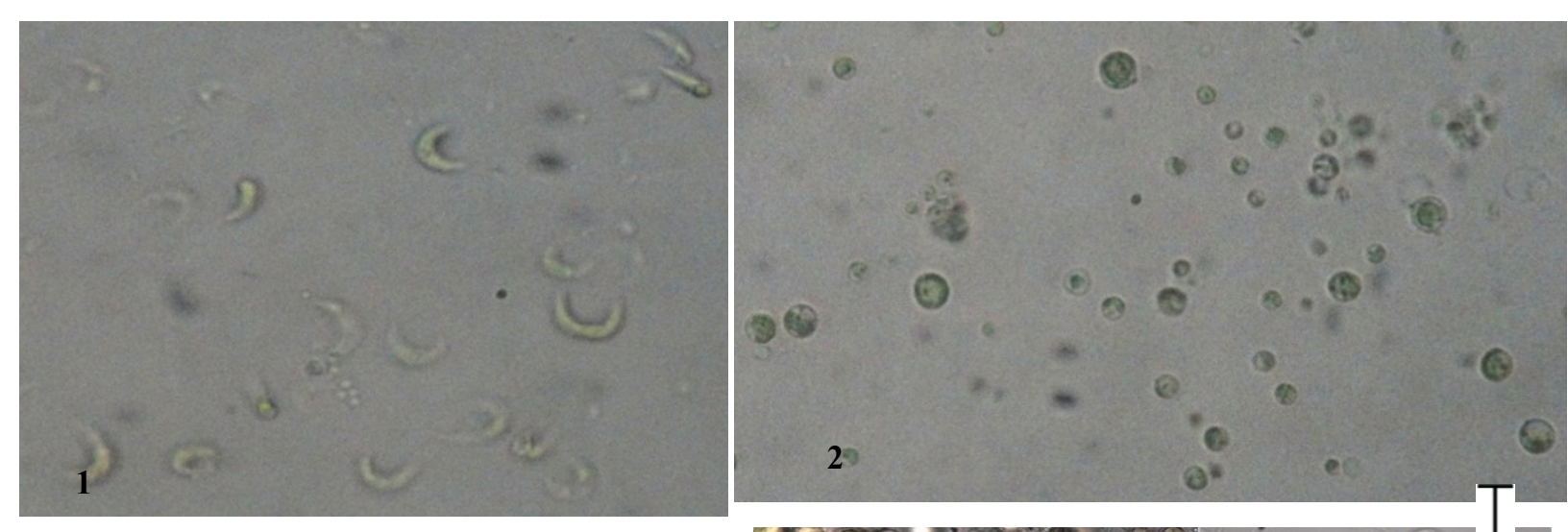

3
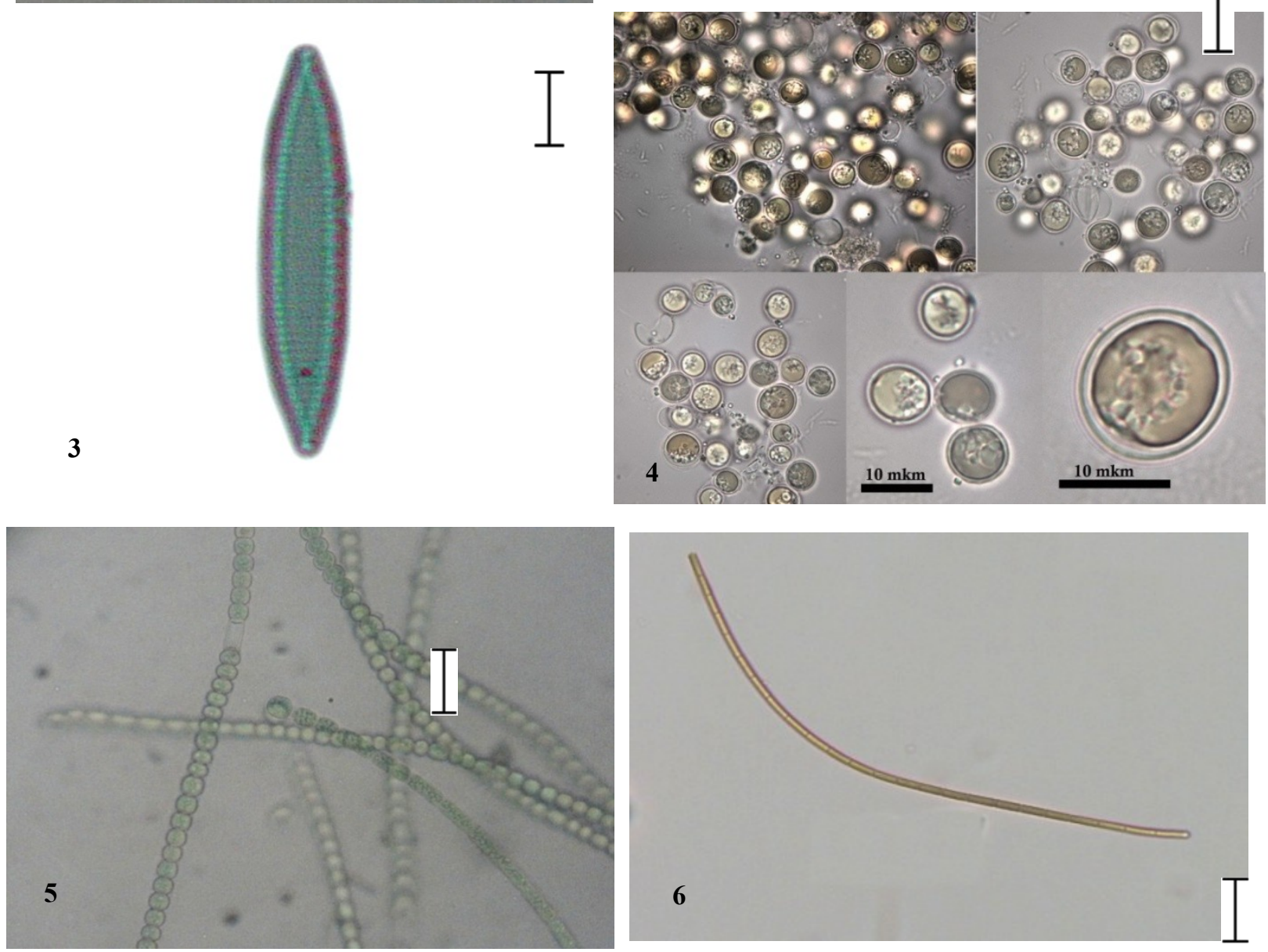

Plate (1): Isolated microalgae figures 1.Ankistrodesmus sp. 2. Chlorellavulgaris 3. Nitzschiapalea 4. Chrysocapsaplanctonica 5. Anabaena sp. 6. Oscillatorialimnetica (eachscalerepresents $10 \mu$ otherwisementioned). 


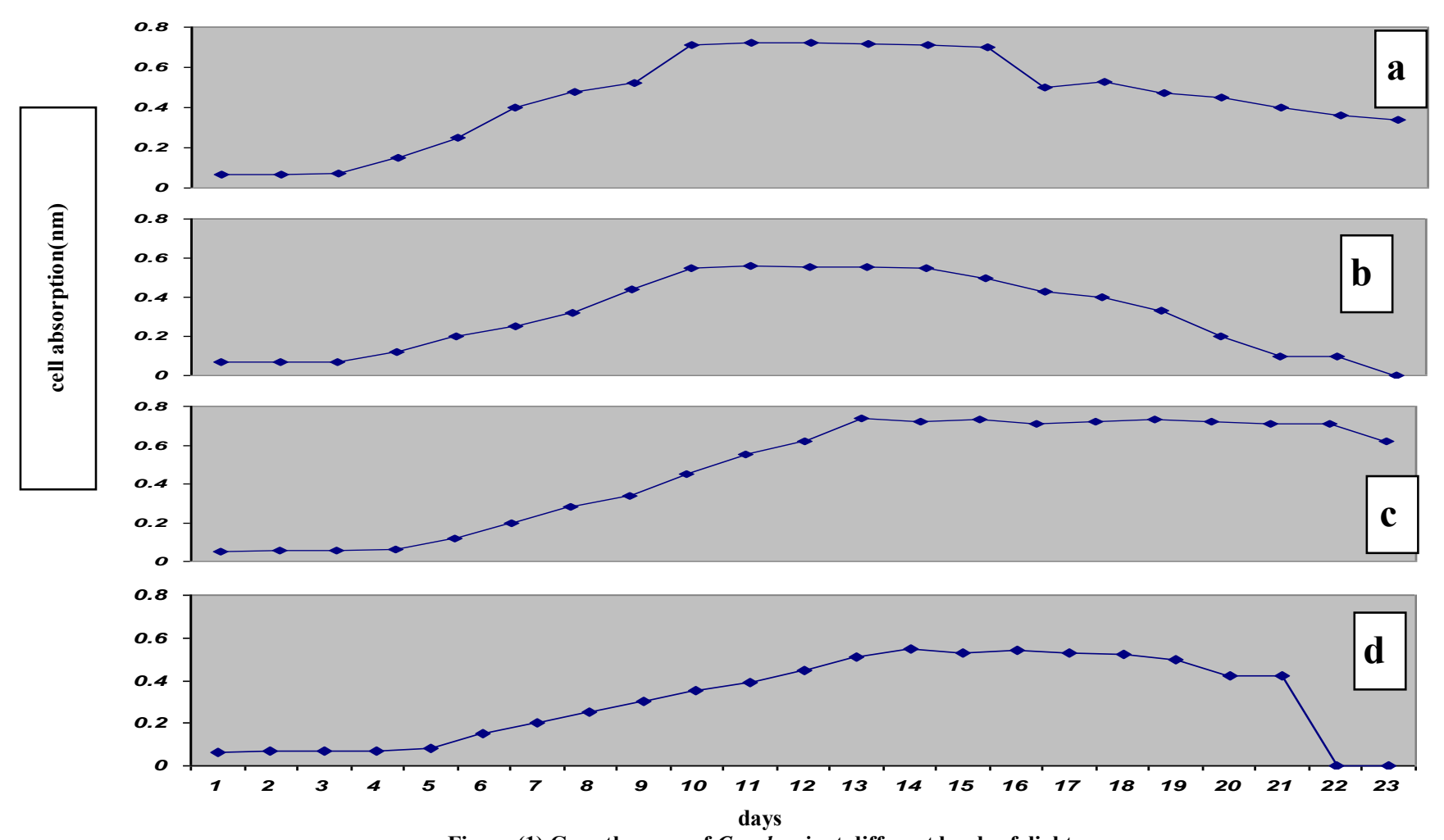

Figure (1) Growth curve of $C$. vulgaris at different levels of light

intensities $\left(\mu \mathrm{E} \backslash \mathrm{m}^{2} \backslash \mathrm{sec}\right): \mathbf{a}=\mathbf{4 0 0} ; \mathbf{b}=\mathbf{3 0 0} ; \mathbf{c}=\mathbf{2 6 8}$ (control); $\mathbf{d = 1 2 5}$
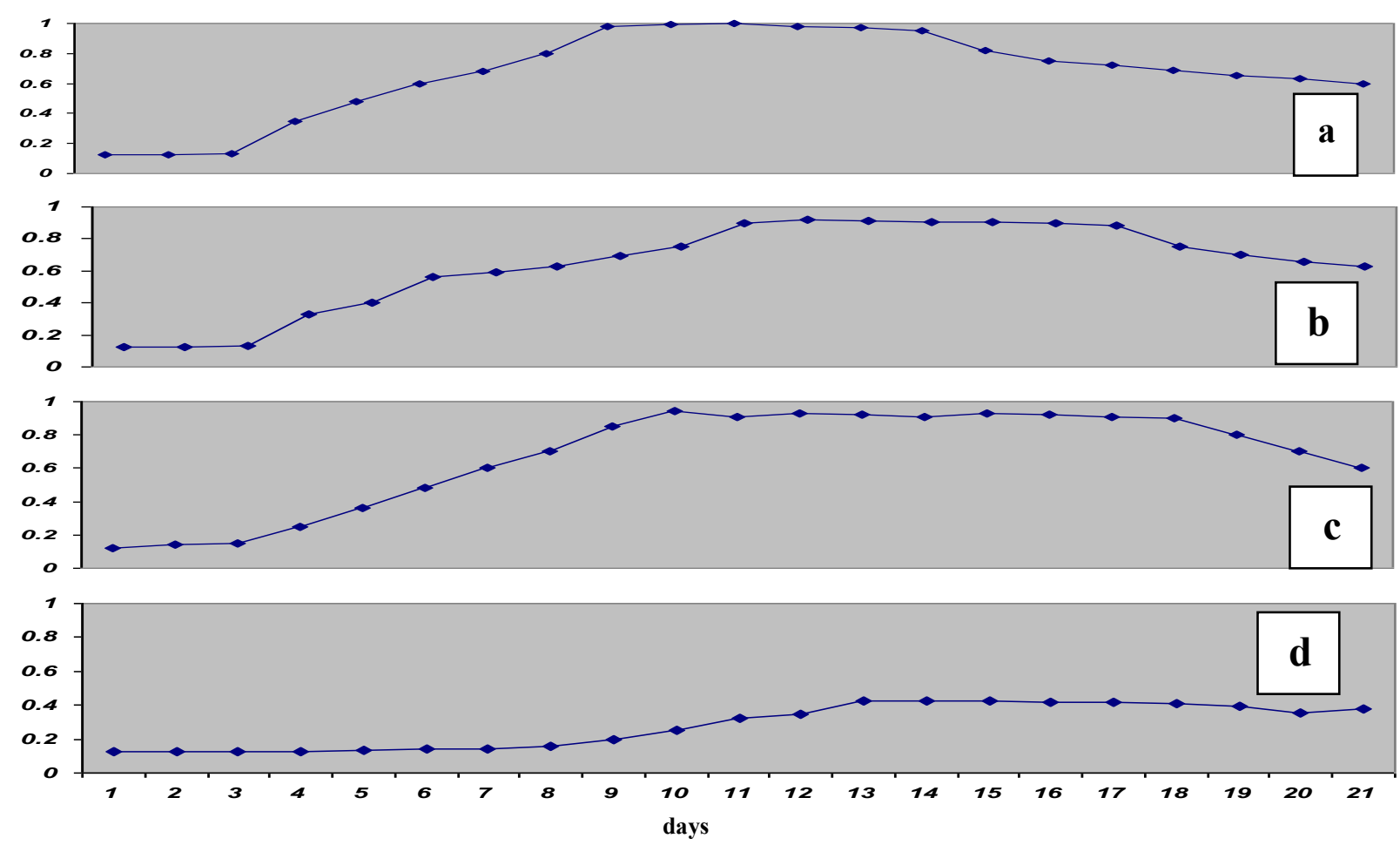

Figure (2) Growth curve of $N$. palea at different light intensities

$\left(\mu \mathrm{E} \backslash \mathrm{m}^{2} \backslash\right.$ sec) $: \quad a=400 ; b=300 ; c=268($ control $) ; d=125$ 


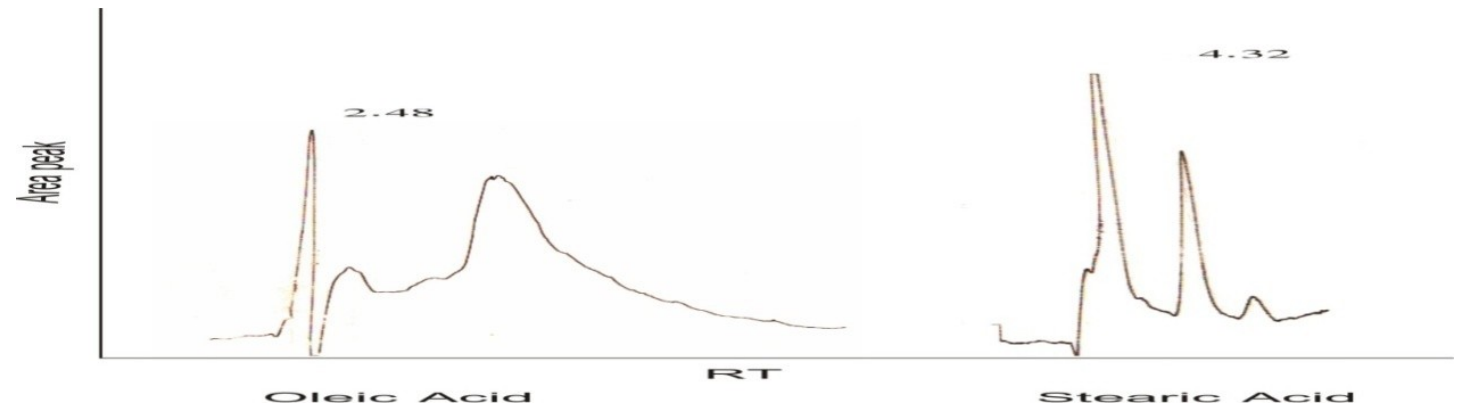

A B

Figure (3) Standars of fatty acids used in the study, and analyzed by HPLC .

Oleic acid, and its Retention Time (RT) is 2.4

Stearic acid, and its Retention Time (RT) is 4.3

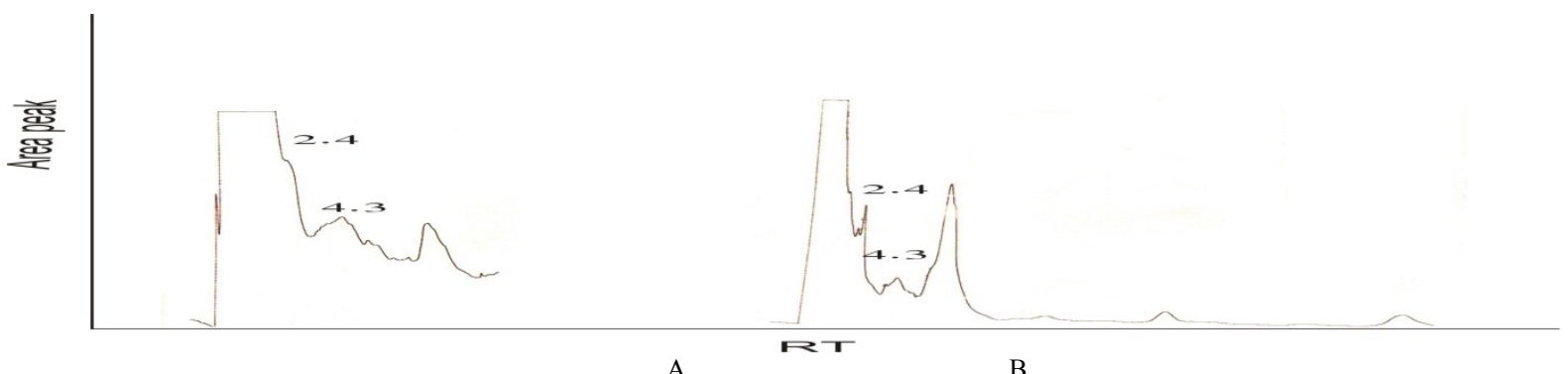

Figure (4): Chromatogram of HPLC for samples of $C$. vulgaris, the (RT) for Oleic acid is 2.4, and the (RT) for Stearic acid is 4.3

(A): the light intensity is $\left(125 \mu \mathrm{E} \backslash \mathrm{m}^{2} \backslash \mathrm{sec}\right)$

(B): the light intensity is $\left(300 \mu \mathrm{E} \backslash \mathrm{m}^{2} \mid\right.$ sec)

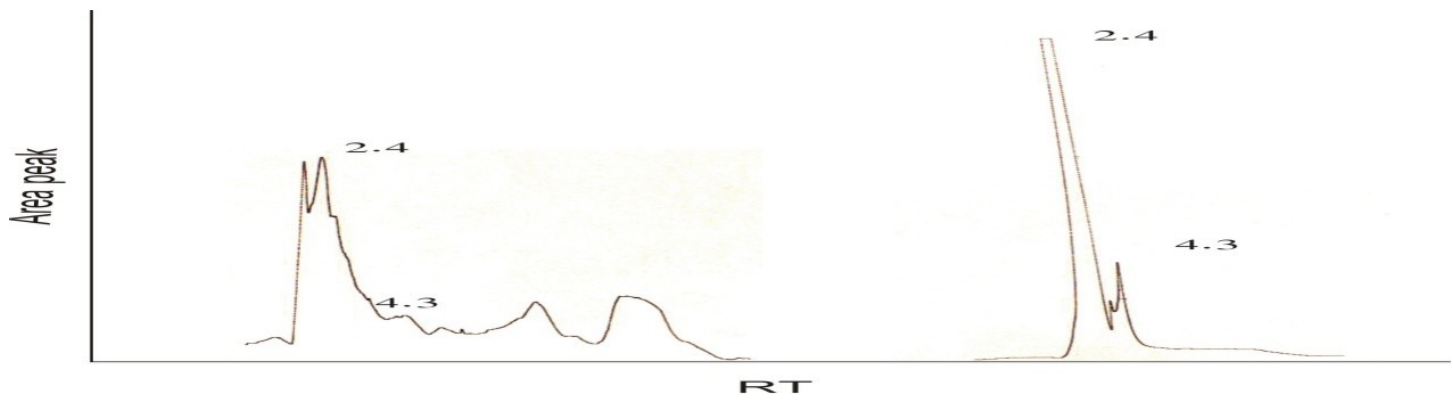

A

B

Figure (5): Chromatogram of HPLC for samples of $N$. palea, the (RT) for Oleic acid is 2.4, and the (RT) for Stearic acid is 4.3

(A): the light intensity is $\left(125 \mu \mathrm{E} \backslash \mathrm{m}^{2} \backslash \mathrm{sec}\right)$

(B): the light intensity is (300 $\mu \mathrm{E} \backslash \mathrm{m}^{2} \backslash$ sec) 